\title{
The influence of credit policy on capital structure via regression analysis
}

\author{
CHEN Yu Ling ${ }^{1, a}$, BAO Ya Jie ${ }^{2, b^{*}}$ \\ ${ }^{1}$ International Education Institute, North China Electric Power University, Beijing, P.R.China \\ ${ }^{2}$ School of Economics and Management,North China Electric Power University, Beijing, P.R.China \\ a253863417@qq.com, bibisi@163.com
}

Keywords: Capital structure; Currency credit policy; Nature of company; Financial Development

\begin{abstract}
Capital structure has been the main research topic of corporate finance and general finance. The policy of currency influence the economy activity and balance capital, and the change of currency credit policy will lead to direct influence financing for foreign trade from banks, thus influence the ability of corporations to gain capital and result in the change of their capital structure.
\end{abstract}

\section{Introduction}

Features of Chinese listed company: low asset-liability ratio, high current liability. At the same time China is in time of transition of market economy, These factors will influence the choice of Chinese listed company. This research aims to analyze these processes and provide the theoretical evidence for government policy and establishment of finance policy of listed company.

The research plan to demonstrate influence of credit policy on capital structure of listed company

Model design. The model design in this research is as below:

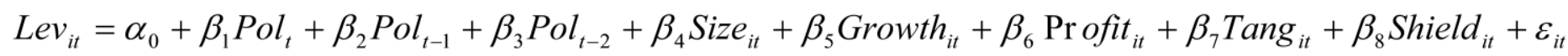

Lev represents company's capital structure; Pol stands for currency credit policy. Size stands for the size of company. Growth stands for company's growth. Profit stands for company's profit. Tang stands for the proportion of company's tangible assets. Shields stands for non-debt tax shield. i stands for the i company. $t$ stands for the $t$ year.

Sample selection. The time span of research is 2000-2013. Sample covers all listed company Shanghai and Shenzhen stock trading center. Sample has been selected for optimization. Final sample: 448 companies from general industry, 6272 samples at year 2014.

\section{Analysis of the result and related solutions}

Descriptive statistics of the sample. The number of state-owned business is over 2 times more than non-state-owned business from 2000-2013. The average assets-liability ratio of non-state-owned business is lower than the state-owned business, while the standard of deviation is higher, which 
means the difference between this group of bigger than the one among state-owned business. Debt payable of non-state-owned business is higher. They tend to get more non-interest debt with their credit, while the liability with interests at non-state-owned business much higher that that of stateowned business.

Analysis on result. This part aims to demonstrate a linear regression analysis on the relevancy between credit policy and corporate structure. Analysis on panel data needs to check by Hausman then choose constant benefit model and random effect model. The result of random effect model is as Table 1, constant benefit model is as Table 2, Hausman result as Table 3.

Table 1 Random effect model

\begin{tabular}{|c|c|c|}
\hline Random-effects GLS regression & Number of obs $=$ & 6272 \\
\hline Group variable: var1 & Number of groups $=$ & 448 \\
\hline $\begin{aligned} \text { R-sq: } \text { within } & =0.3010 \\
\text { between } & =0.2710 \\
\text { overall } & =0.2814\end{aligned}$ & $\begin{array}{r}\text { Obs per group: } \min = \\
\operatorname{avg}= \\
\max =\end{array}$ & $\begin{array}{l}14 \\
14.0 \\
14\end{array}$ \\
\hline $\begin{array}{l}\text { Random effects } u_{-} i \sim \text { Gaussian } \\
\operatorname{corr}\left(u_{-} i, \quad X\right) \quad=0 \text { (assumed) }\end{array}$ & $\begin{array}{c}\text { Wald chi2(9) }= \\
\text { Prob }>\operatorname{chi} 2=\end{array}$ & $\begin{array}{l}2662.40 \\
0.0000\end{array}$ \\
\hline
\end{tabular}

\begin{tabular}{|c|c|c|c|c|c|c|}
\hline lev & Coef. & Std. Err. & $\mathrm{z}$ & $\mathrm{P}>|\mathrm{z}|$ & \multicolumn{2}{c|}{ [95\% Conf. Interval] } \\
\hline var4 & 0.056964 & 0.023894 & 2.38 & 0.017 & 0.0101331 & 0.103796 \\
\hline var5 & 0.054877 & 0.023856 & 2.30 & 0.021 & 0.0081204 & 0.101633 \\
\hline var6 & -0.01509 & 0.023433 & -0.64 & 0.519 & -0.0610224 & 0.030834 \\
\hline var7 & 0.159907 & 0.004146 & 38.57 & 0.000 & 0.1517803 & 0.168033 \\
\hline var8 & -0.00052 & 0.000112 & -4.64 & 0.000 & -0.0007385 & -0.0003 \\
\hline var9 & 0.080346 & 0.015832 & 5.08 & 0.000 & 0.0493164 & 0.111376 \\
\hline var10 & -0.78411 & 0.037201 & -21.08 & 0.000 & -0.8570221 & -0.7112 \\
\hline var11 & 0.104498 & 0.010724 & 9.74 & 0.000 & 0.0834807 & 0.125516 \\
\hline var12 & -1.56543 & 0.126381 & -12.39 & 0.000 & -1.813133 & -1.31773 \\
\hline cons & -1.00772 & 0.038427 & -26.22 & 0.000 & -1.083037 & -0.9324 \\
\hline sigma_u & .10982608 & & & & & \\
\hline sigma_e & .09571696 & \multicolumn{7}{|l|}{} & & & \\
\hline rho & .56832119 (fraction of variance due to u_i) \\
\hline
\end{tabular}


var3 $\mid \quad$ Coef. Std. Err. z $\quad$ P $>|z| \quad$ [95\% Conf. Interval]

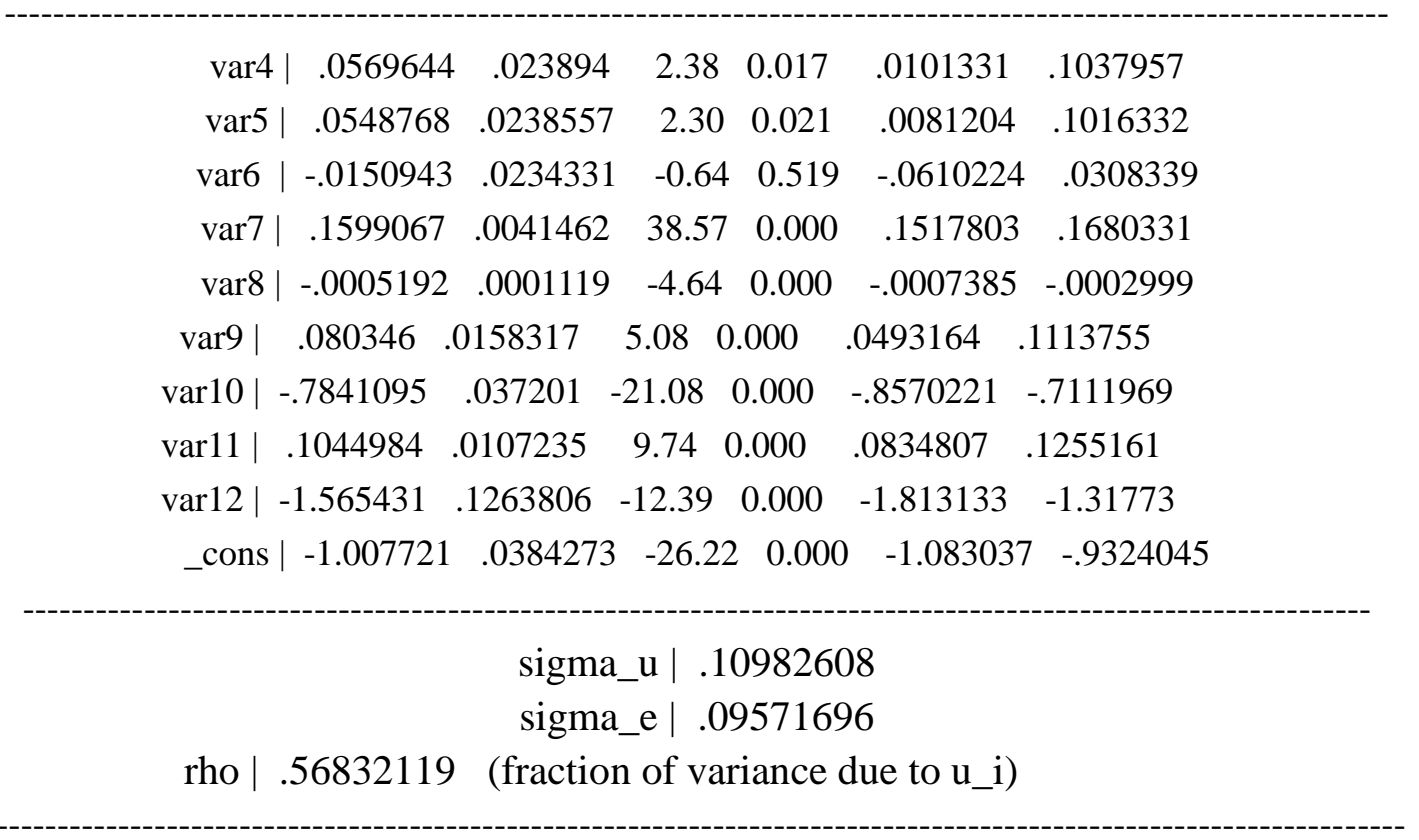

Table 2 Constant benefit model

\begin{tabular}{|c|c|c|c|c|c|}
\hline $\operatorname{var} 3 \mid$ & Coef. Std. Err. & t $\quad P>|t|$ & {$[95 \%$} & Conf. Interva & ral] \\
\hline $\operatorname{var} 4$ & $\begin{array}{ll}0481408 & .0238609\end{array}$ & 2.02 & 0.044 & .0013645 & .094917 \\
\hline $\operatorname{var} 5$ & $\begin{array}{ll}.0453031 \quad 0238019\end{array}$ & 1.90 & 0.057 & -.0013574 & .0919637 \\
\hline var6 | & -0259338 .0235276 & -1.10 & 0.270 & -.0720568 & .0201891 \\
\hline $\operatorname{var} 7 \mid$ & .1665546 .0044606 & 37.34 & 0.000 & .1578102 & .175299 \\
\hline var8 & -.0004485 & -3.99 & 0.000 & -.000669 & -.000228 \\
\hline var9| & $.0740843 \quad 0158067$ & 4.69 & 0.000 & .0430973 & .1050713 \\
\hline $\operatorname{var10}$ & -.7597004 .0373777 & -20.32 & 0.000 & -.8329747 & -.6864261 \\
\hline $\operatorname{var} 11 \mid$ & $\begin{array}{ll}.1047585 & .0109487\end{array}$ & 9.57 & 0.000 & 083295. & .1262221 \\
\hline $\operatorname{var} 12$ & -1.450094 .1324856 & -10.95 & 0.000 & -1.709815 & -1.190372 \\
\hline _cons | & $-1.068446 \quad .0410471$ & -26.03 & 0.000 & -1.148913 & -.987978 \\
\hline \multicolumn{6}{|c|}{$\begin{array}{c}\text { sigma_u } \mid .12146976 \\
\text { sigma_e } \mid .09571696 \\
.61693042 \text { (fraction of variance due to u_i) }\end{array}$} \\
\hline
\end{tabular}

F test that all $\mathrm{u} \_\mathrm{i}=0: \quad \mathrm{F}(447, \quad 5815)=20.95 \quad$ Prob $>\mathrm{F}=0.0000$

Fixed-effects (within) regression

Group variable: var1

R-sq: within $=0.3015$

between $=0.2613$
Number of obs $=6272$

Number of groups $=448$

Obs per group: $\min =14$

$\operatorname{avg}=14.0$ 
overall $=0.2749$

$\max =14$

$\operatorname{corr}\left(\mathrm{u} \_\mathrm{i}, \quad \mathrm{Xb}\right)=-0.0858$

$\mathrm{F}(9,5815)=278.86$

Prob $>\mathrm{F}=0.0000$

\begin{tabular}{|c|c|c|c|c|c|c|}
\hline lev & Coef. & Std. Err. & $\mathrm{z}$ & $\mathrm{P}>|\mathrm{z}|$ & \multicolumn{2}{c|}{ [95\% Conf. Interval] } \\
\hline var4 & 0.0481408 & 0.023861 & 2.02 & 0.044 & 0.001365 & 0.094917 \\
\hline var5 & 0.0453031 & 0.023802 & 1.90 & 0.057 & -0.00136 & 0.091964 \\
\hline var6 & -0.025934 & 0.023528 & -1.10 & 0.270 & -0.07206 & 0.020189 \\
\hline var7 & 0.1665546 & 0.004461 & 37.34 & 0.000 & 0.15781 & 0.175299 \\
\hline var8 & -0.000449 & 0.000113 & -3.99 & 0.000 & -0.00067 & -0.00023 \\
\hline var9 & 0.0740843 & 0.015807 & 4.69 & 0.000 & 0.043097 & 0.105071 \\
\hline var10 & -0.7597 & 0.037378 & -20.32 & 0.000 & -0.83297 & -0.68643 \\
\hline var11 & 0.1047585 & 0.010949 & 9.57 & 0.000 & 0.083295 & 0.12622 \\
\hline var12 & -1.450094 & 0.132486 & -10.95 & 0.000 & -1.70982 & -1.19037 \\
\hline cons & -1.068446 & 0.041047 & -26.03 & 0.000 & -1.14891 & -0.98798 \\
\hline sigma_u & 0.1214698 & & & & & \\
\hline sigma_e & 0.0571696 & \multicolumn{7}{l}{ Prob $>\mathrm{F}=0.0000$} & \\
\hline rho & 0.6169304261693042 (fraction of variance due to u_i) \\
\hline F test that all u_i=0: F(447, 5815) = 20.95
\end{tabular}

Table 3 Hausmann

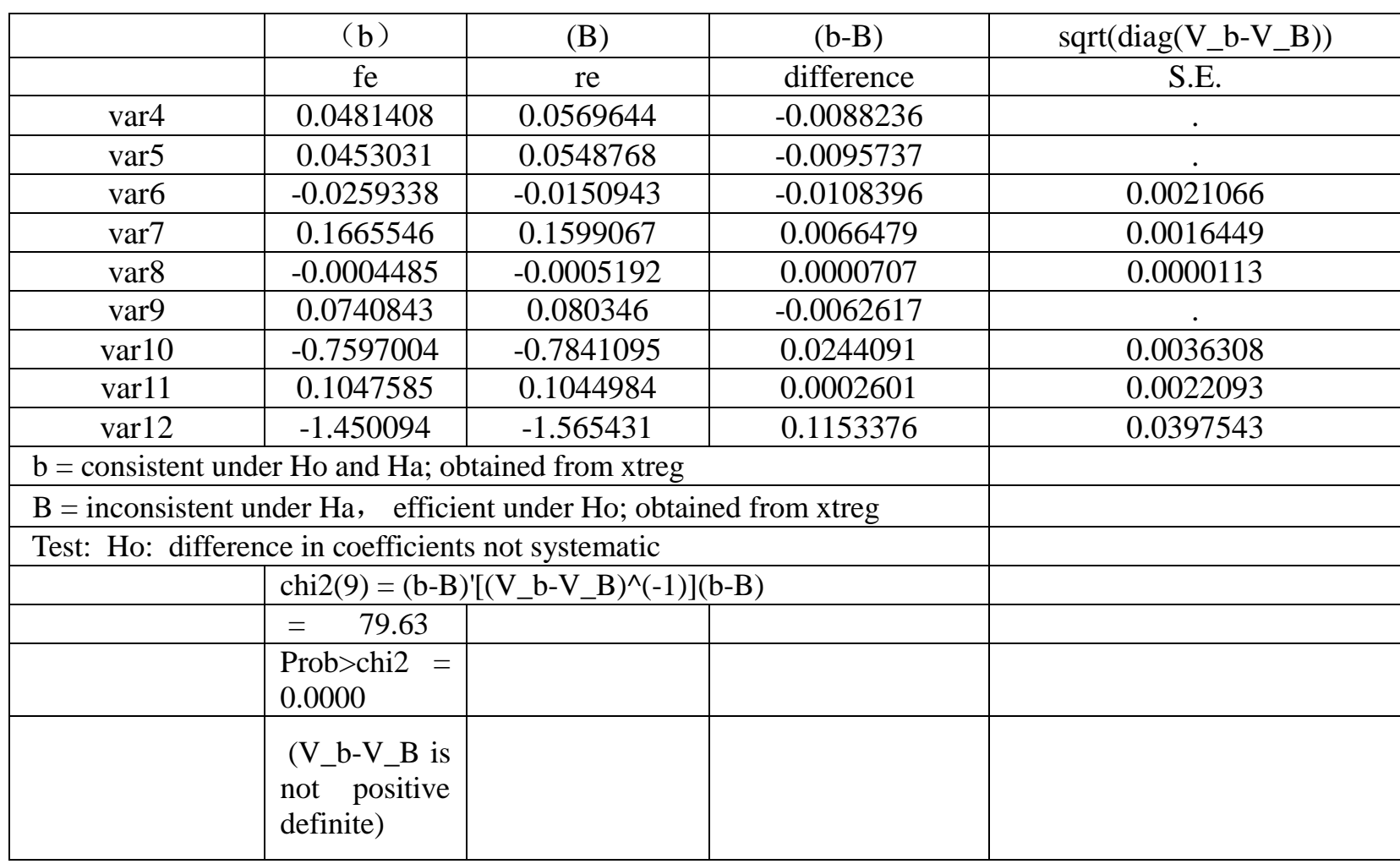

It is showed as above that $\mathrm{P}: 0<0.05$, while chi 79.63 is positive, therefore the panel data regression denies random effect. The constant benefit model should be used for it.

Further analysis is as Table 2. Variables sum as 6272. Group variable is time. There are 448 groups, i.e. we could see stata regression of constant benefit in 448 companies between 2000-2013. Goodness-of-fit of this model: 0.3015 within group and 0.613 among groups, averaging 0.2749. 
Column coef stands for variables and relativeness between variables. There is negative correlation between variable $6,8,10$ and 12, the rest are with positive correlation. The $P$ of variable 6 equals 0.270 , which exceeds $10 \%$. Therefore variable 6 (credit policy in year $\mathrm{t}-2$ ) should be excluded, which means the relativeness of capital structure between year $t$ and $t-2$ is weak. Variable 4 and 5 is within $5 \%$, and the $\mathrm{P}$ of variable $7-12$ equals 0.000 , which means the relativeness between them is strong. Result: the relativeness of capital structure of listed company between year t-1 and t-2 is weak. This is because the incremental rate of loan balance of inland finance department is used as index for currency policy.

\section{Conclusion and Proposal}

The influence of currency credit policy is different on debt ratio of different kinds of business, on capital structure of different areas with finance development difference, and on company with different operation results. Therefore, we need to accelerate the market reform of company bonds, we need to balance the finance development among areas.

\section{References}

[1] D Durand. Costs of Debt and Equity Funds for Business: Trends and Problems of Measurement [Z].Conference on Research in Business Finance, 1952

[2] DeAngelo, H. and R. Masulis, Optimal capital structure under corporate and Personal taxation [J], Journal of Financial Economics.1980, 3-29

[3] Dincergok, B. \& Yalciner, K. (2011) Capital structure decisions of manufacturing firms' in developing countries, Middle Eastern finance and economics, 12, April, 2011, 86-100

[4] Keshtkar, R. Valipour, H. \& Javanmard, A. (2012) Determinants of corporate capital structure under different debt maturities: empirical evidence from Iran, International research journal of finance and economics, 90, May, 46-53

[5] Bhaumika, Dangb,Kutan Implications of bank ownership for the credit channel of monetary policy transmission: Evidence from India

[6] Lim M, T. C. (2012). Determinants of capital structure: empirical evidence from financial services listed firms in China, International journal of economics and finance, 4(3), 191-203

[7] Kouki, M. \& Said, H. B. (2012). Capital structure determinants: new evidence from French panel data, International journal of business and management, 7(1), 214-229

[8] Matteo Iacoviello, Raoul Minetti. The Credit Channel of Monetary Policy: Evidence from the Housing Market [J]. Journal of Macroeconomics, 2008, Vol 30, N0.1:69-96

[9] Iris Claus .Inside the black box: How important is the credit channel relative to the interest and exchange rate channels? [J] Economic Modeling, 2011, Volume 28, Issues 1-2, Pages 1-12

[10] Ries Wulandari Do Credit Channel and Interest Rate Channel Play Important Role in Monetary Transmission Mechanism in Indonesia?: A Structural Vector Autoregression Model 